\title{
Effect of Different Vitamin D Sources and Calcium Levels in the Diet of Layers in the Second Laying Cycle
}

\section{-Author(s) \\ Nascimento GR do \\ Murakami $A E^{\prime}$ \\ Guerra AFQM' \\ Ospinas-Rojas $\mid \mathrm{C}^{\mathrm{I}}$ \\ Ferreira MFZ \\ Fanhani J $\mathrm{C}^{\prime}$}

Departamento de Zootecnia, Universidade Estadual de Maringá, Avenida Colombo 5790, Jardim Universitário, Maringá, PR 87020-900, Brazil.

\section{Mail Adress}

Corresponding author e-mail address

Departamento de Zootecnia, Universidade Estadual de Maringá, Avenida Colombo 5790, Jardim Universitário, Maringá, PR 87020-900, Brazil.

E-mail: aemurakami@uem.br; guirodnas@hotmail.com

\section{nKeywords}

Cholecalciferol, 25 hydroxycholecalciferol, 1.25 dihydroxycholecalciferol.

\section{ABSTRACT}

This study evaluated the effects of different sources of vitamin D and calcium levels on performance, egg quality and bone strength of hens in the second production cycle. A total of 384 Hy-Line W36 birds with 80 weeks of age were used, alloted into $3 \times 4$ factorial design (sources of vitamin D: cholecalciferol; $25(\mathrm{OH}) \mathrm{D}_{3}$ and $1.25(\mathrm{OH})_{2} \mathrm{D}_{3} \times$ calcium levels: $2.85,3.65 ; 4.45$ and $5.25 \%$ ) with four replicates and eight birds each. The performance was evaluated for three cycles of 28 days each, egg quality was evaluated in the last four days of each cycle and bone strength on the last day of the experimental period. There was no interaction ( $p>0.05$ ) between the different sources of vitamin $\mathrm{D}$ and calcium levels in all parameters evaluated. There was a quadratic effect $(p<0.05)$ of calcium levels in egg production and feed conversion $(\mathrm{kg} / \mathrm{kg}$ and $\mathrm{kg} / \mathrm{dz})$, with better results at levels of $4.12 \%, 4.09 \%$ and $4.14 \%$, respectively. Calcium levels had no effect ( $p>0.05)$ in the egg weight and Haugh unit, but there was a linear increase $(p<0.05)$ in the percentage and eggshell thickness, in specific gravity and bone strength. The different sources of vitamin D influenced $(p<0.05)$ the egg production rate, feed conversion, egg weight and Haugh unit. Thus, the results of this study suggest that the recommended calcium level for laying on second cycle is between $4.09 \%$ and $4.14 \%$ and that the metabolites cholecalciferol and $25(\mathrm{OH}) \mathrm{D}_{3}$ improved the performance and egg quality. Regarding bone strength was improved as the calcium levels were increased in diets.

\section{INTRODUCTION}

During the second laying cycle, after forced molting, layers restore their calcium absorption levels, with resulting eggshell quality improvement. However, this effect is independent of egg size, and therefore, eggshell quality worsens as birds age (Albano Jr et al., 2000).

During the second laying cycle, commercial layers present high egg loss due to poor eggshell quality and weak bones due to calcium mobilization. Therefore, their calcium and vitamin $D$ requirements need to be updated to improve egg quality and the productivity of the egg industry.

Calcium is required for several metabolic functions in poultry (Nunes et al., 2006) and to ensure good eggshell quality. Its functions are also associated with phosphorus and vitamin $\mathrm{D}_{3}$. During eggshell synthesis, blood calcium is rapidly mobilized, thereby reducing its levels. This stimulates the secretion of the parathyroid hormone (PTH), which promotes bone resorption to reestablish calcium homeostasis (Pelícia et al. 2009). The high rates of bone resorption during lay result in bone weakness in layers by the end of their production cycle (Whitehead, 2004). 
Vitamin $D_{3}$ can be synthesized in the skin, catalyzed by ultraviolet radiation, from 7-dihydrocholesterol present in the dermis and epidermis (Pedrosa \& Castro, 2005) or can be supplied in the feed. Commercial layers are usually maintained indoors, and do not receive enough solar radiation to convert 7-dihydrocholesterol in sufficient levels to supply their vitamin $D_{3}$ requirements. This is why vitamin $D_{3}$ is routinely added to layer feeds, which is essential for the maintenance of egg production, eggshell formation, and calcium homeostasis.

Cholecalciferol $\left(D_{3}\right)$ is the most common form of vitamin $\mathrm{D}$ added to feeds. After absorption by the intestinal mucosa, it is transported to the liver, where it is hydroxylated in the position 25, resulting in 25-hydroxycholecalciferol $\left(25(\mathrm{OH}) \mathrm{D}_{3}\right)$. This metabolite is directed to the kidneys and hydroxylated at carbon 1 , originating the active metabolite of vitamin $D$, 1,25-dihydroxycholecalciferol $\left(1,25(\mathrm{OH})_{2} \mathrm{D}_{3}\right)$ (Leeson \& Summers, 2001)

The inclusion of different vitamin $D$ metabolites in the diet may enhance the effect of vitamin $D$ due to their ready availability, sparing the chain of reactions required for the synthesis of the active metabolite.

Therefore, this study aimed at the evaluating the effects of different dietary vitamin $D$ sources and calcium levels on the production performance, egg quality, and bone strength of layers in their second laying cycle.

\section{MATERIALS AND METHODS}

The experiment was carried out at the poultry sector of the experimental farm of Iguatemi, State University of Maringá, Brazil. The experiment was approved by the Committee of Ethics and Animal Welfare of that university, under protocol n. 023/2013.

In the trial, 384 80-wk-old Hy-line ${ }^{\circledR}$ W36 layers were housed in battery cages $\left(100 \times 40 \times 45 \mathrm{~cm}^{3}\right)$, at a density of $500 \mathrm{~cm}^{2} / \mathrm{bird}$, an open-sided layer house covered with clay tiles.

A completely randomized experimental design in a $3 \times 4$ factorial arrangement, consisting of three vitamin D sources (cholecalciferol; $25(\mathrm{OH}) \mathrm{D}_{3}$ and $1,25(\mathrm{OH})_{2} \mathrm{D}_{3}$ ) and four dietary calcium levels $(2.85,3.65,4.45,5.25)$, with four replicates of eight birds per experimental unit, was applied.

Average maximum and minimum environmental temperatures recorded during the experimental period were $29.2^{\circ} \mathrm{C}$ and $16.6^{\circ} \mathrm{C}$, respectively.
Feeds were based on corn and soybean meal, supplemented with vitamins and trace minerals, and formulated according to the recommendations of Rostagno et al. (2011), except for calcium levels. The different vitamin $\mathrm{D}$ sources were included in the diet to supply $2000 \mathrm{IU}$ of vitamin $\mathrm{D}_{3}$. The vitamin supplement did not contain vitamin $\mathrm{D}$. The experimental diets are shown in Table 1.

Table 1 - Ingredients and nutritional composition of the experimental diets.

\begin{tabular}{|c|c|c|c|c|}
\hline \multirow[t]{2}{*}{ Ingredients } & \multicolumn{4}{|c|}{ Calcium levels } \\
\hline & 2.85 & 3.65 & 4.45 & 5.25 \\
\hline Corn & 70 & 70 & 68.74 & 64.47 \\
\hline Soybean meal $45 \%$ & 15.98 & 15.98 & 16.27 & 16.99 \\
\hline Soybean oil & 0.605 & 0.605 & 1.021 & 2.48 \\
\hline Dicalcium phosphate & 2.082 & 2.082 & 2.080 & 2.099 \\
\hline Limestone & 5.94 & 8.02 & 10.1 & 12.18 \\
\hline Salt & 0.420 & 0.420 & 0.420 & 0.420 \\
\hline Vitamin and mineral suppl. ${ }^{1}$ & 0.250 & 0.250 & 0.250 & 0.250 \\
\hline Inert materia| ${ }^{2}$ & 3.846 & 1.762 & 0.250 & 0.250 \\
\hline Sodium bicarbonate & 0.420 & 0.420 & 0.420 & 0.420 \\
\hline L-Lysine HCL 78.5\% & 0.123 & 0.123 & 0.117 & 0.105 \\
\hline DL-Methionine 99\% & 0.185 & 0.185 & 0.186 & 0.192 \\
\hline L-threonine $98 \%$ & 0.051 & 0.051 & 0.05 & 0.05 \\
\hline L-valine 98\% & 0.068 & 0.068 & 0.067 & 0.068 \\
\hline L-tryptophan 98\% & 0.02 & 0.02 & 0.019 & 0.017 \\
\hline $\mathrm{BHT}^{3}$ & 0.01 & 0.01 & 0.01 & 0.01 \\
\hline \multicolumn{5}{|l|}{ Calculated nutritional composition } \\
\hline Metabolizable energy $(\mathrm{kcal} / \mathrm{kg})$ & 2800 & 2800 & 2800 & 2800 \\
\hline Crude protein (\%) & 13.35 & 13.35 & 13.37 & 13.34 \\
\hline Digestible lysine (\%) & 0.650 & 0.650 & 0.650 & 0.650 \\
\hline Digestible Met + Cys (\%) & 0.590 & 0.590 & 0.590 & 0.590 \\
\hline Digestible valine (\%) & 0.620 & 0.620 & 0.620 & 0.620 \\
\hline Dig. tryptophan (\%) & 0.150 & 0.150 & 0.150 & 0.150 \\
\hline Calcium (\%) & 2.850 & 3.650 & 4.450 & 5.250 \\
\hline Available phosphorus (\%) & 0.470 & 0.470 & 0.470 & 0.470 \\
\hline Chlorine (\%) & 0.293 & 0.2933 & 0.2929 & 0.291 \\
\hline Sodium (\%) & 0.297 & 0.2973 & 0.297 & 0.2964 \\
\hline Potassium (\%) & 0.489 & 0.4885 & 0.49 & 0.4915 \\
\hline Electrolyte balance $(\mathrm{mEg} / \mathrm{kg})$ & 172 & 172 & 172 & 173 \\
\hline
\end{tabular}

1 Vitamin and mineral supplement (content/kg product): vit. A - $3600 \mathrm{IU}$; vit. E - 3200 IU; vit. K - 800 mg; vit. B1 - 500 mg; vit. B2 - 1600 mg; Vit. B6 - 500 mg; Vit. B12 - $4000 \mathrm{mcg}$; niacin - $8000 \mathrm{mg}$; calcium pantothenate - $3200 \mathrm{mg}$; Se - $100 \mathrm{mg}$; Mn 24 g; Zn - 20 g; Cu - 4.800 mg; I - 400 mg; Fe - 20 g; Co - 80 mg.

${ }^{2} V$ itamins $\mathrm{D}_{3}, 25(\mathrm{OH}) \mathrm{D}_{3}$ and $1.25(\mathrm{OH}) 2 \mathrm{D}_{3}$ were included at the expense of inert material at $2000 \mathrm{IU}$ at the following levels: $400 \mathrm{mg}, 5 \mathrm{mg}$, and $200,000 \mathrm{mg}$, respectively.

${ }^{3} \mathrm{BHT}=$ antioxidant butyl-hidroxytoluene at $4000 \mathrm{mg}$. 
A lighting program of $17 \mathrm{~h}$ of light (natural + artificial) per day was adopted. Feed and water were supplied ad libitum. Birds were submitted to a 14-day adaptation period and evaluated for three periods of 28 days each. Feed intake (g/bird/day) and feed conversion ratio $(\mathrm{kg} / \mathrm{kg}$ and $\mathrm{kg} / \mathrm{dz})$ were evaluated in each period by weighing feed offer in the beginning and at the end of each period. Eggs were collected daily to determine egg production.

Eggs were collected during the last four days of each period to determine average egg weight and egg specific gravity. A sample of three eggs per replicate out of the total eggs produced per cage as collected to determine albumen height, and eggshell percentage and thickness.

Egg specific gravity was determined by immersing eggs in saline solutions at different concentrations (1.070, 1.074, 1.078, 1.082, and $1.086 \mathrm{~g} / \mathrm{mL})$. Saline solutions were adjusted using an oil densitometer and regularly calibrated.

Egg internal quality was evaluate relative to Haugh units, as described by Brant \& Shrader (1958), where $H U=100 \log \left(H+7.57-1.7 W^{0.37}\right)$, where $H=$ albumen height $(\mathrm{mm})$ and $\mathrm{W}=$ egg weight $(\mathrm{g})$.

Eggshells with the internal membrane were washed under running water and then dried at environmental temperature for 72 hours (Maia et al., 2002; Costa et al., 2011), and dried in a digital scale to determine its weight relative to egg weight.

Eggshell thickness was determined using a digital micrometer (Mitutoyo $®$ ) with $0.001-\mathrm{mm}$ precision. Measures were taken at the egg equator, where the distribution of calcium carbonate crystals is homogenous (Murakami et al., 2006).

Bone strength was evaluated in the left tibia of two hens per experimental unit, which was collected and frozen $\left(-18^{\circ} \mathrm{C}\right)$ until analyses. Legs were thawed, the muscle tissue adhered to the bone was removed with the aid of scissors and forceps, and the tibiae were separated. Bone strength was analyzed in thawed bones at the Laboratory of Construction Materials and Soil Mechanics of the Technology Center of UEM. The mechanism consisted of a base that supported bone epiphyses and the force was applied in the central region of the bone.Values are expressed in kilogramsforce $(\mathrm{kgf})$.

In order to evaluate the influence of vitamin $D$ sources on calcium metabolism, blood samples were collected every six hours for 24 hours, starting one hour after egg lay. Blood was collected by wing-vein puncture from one hen per experimental unit in each of the five blood collections. Serum calcium level was determined using a commercial kit.

Orthogonal polynomials were calculated for the obtained data for analysis of variance and analysis of regression. Means were compared by the test of Tukey at $5 \%$ probability level using the System of Statistical and Genetic Analyses (SAEG-8.0), developed by the Federal University of Viçosa (2005).

\section{RESULTS AND DISCUSSION}

There was no interaction ( $p>0.05$ ) between vitamin $D$ sources and calcium levels for none of the evaluated performance and egg quality parameters, or bone strength (Tables 2 and 3).

Dietary calcium levels did not influence ( $p>0.05)$ feed intake. Costa et al. (2008) tested 3.0-5.0\% dietary calcium levels and did not find any effects on feed intake. On the other hand, Araújo et al. (2011) verified lower feed intake when calcium level was increased from 3.5 to $4.2 \%$ in the diet of commercial layers in the post-molting period.

Egg production and feed conversion ratio $(\mathrm{kg} / \mathrm{kg}$ and $\mathrm{kg} / \mathrm{dz}$ ) presented quadratic responses $(p<0.05)$. The resulting calcium requirement estimates of 4.12 , 4.09 , and $4.14 \%$ for second-cycle layers are higher than that reported by Rodrigues et al. (2005), who recommended a level of $3.5 \%$ calcium in the diet of these layers.

The obtained calcium values are close to that recommended by Rostagno et al. (2011), of 3.9\% calcium for commercial layers and below the recommendations of the Hy-Line W36 manual (2011), of $4.67 \%$ calcium in the diet of layers producing less than $75 \%$ eggs.

Among the tested vitamin $D$ sources, the hens fed $D_{3}$ presented higher egg production $(p<0.05)$ compared with those fed $1,25(\mathrm{OH})_{2} \mathrm{D}_{3}$, which, however, was not different from those fed $25(\mathrm{OH}) \mathrm{D}_{3}$. The hens fed $25(\mathrm{OH}) \mathrm{D}_{3}$ presented better feed conversion ratio $(\mathrm{kg} /$ $\mathrm{kg}$ and $\mathrm{kg} / \mathrm{dz} ; \mathrm{p}<0.05)$ relative to $1,25(\mathrm{OH})_{2} \mathrm{D}_{3}$, but similar results $(p>0.05)$ as the group fed $D_{3}$.

Evaluating the effects of the inclusion of vitamin $\mathrm{D}_{3}$ or metabolite $25(\mathrm{OH}) \mathrm{D}_{3}$ in layer diets, Salvador et al. (2009) obtained better feed conversion ratio with $25(\mathrm{OH}) \mathrm{D}_{3}$. On the other hand, Hamilton (1980) observed that $\mathrm{D}_{3}$ promoted better egg production and feed conversion ratio $(\mathrm{kg} / \mathrm{kg})$ results relative to $25(\mathrm{OH})$ $\mathrm{D}_{3}$.

Egg weight (g) was not influenced by dietary calcium levels. However, the hens fed the metabolite $25(\mathrm{OH}) \mathrm{D}_{3}$ 
Table 2 - Performance of commercial layers in their second laying cycle fed diets with different vitamin D sources and calcium levels.

\begin{tabular}{|c|c|c|c|c|c|}
\hline Parameters & Egg production (\%) & Egg weight (g) & $\begin{array}{l}\text { Feed intake (g/bird/ } \\
\text { day) }\end{array}$ & $\begin{array}{c}\text { Feed conversion ratio } \\
(\mathrm{kg} / \mathrm{kg})\end{array}$ & $\begin{array}{l}\text { Feed conversion ratio } \\
(\mathrm{kg} / \mathrm{dz})\end{array}$ \\
\hline \multicolumn{6}{|l|}{ Vitamin D } \\
\hline Cholecalciferol & $73.27 \pm 0.58 a$ & $69.77 \pm 0.21 \mathrm{ab}$ & $107.13 \pm 0.34$ & $2.135 \pm 0.01 \mathrm{ab}$ & $1.858 \pm 0.03 a b$ \\
\hline 25-hydroxycholecalciferol & $72.08 \pm 0.75 a b$ & $69.97 \pm 0.33 a$ & $106.44 \pm 0.28$ & $2.092 \pm 0.02 a$ & $1.781 \pm 0.03 a$ \\
\hline 1,25-dihydroxycholecalciferol & $70.17 \pm 1.04 b$ & $68.95 \pm 0.26 b$ & $107.35 \pm 0.53$ & $2.215 \pm 0.04 b$ & $1.894 \pm 0.04 b$ \\
\hline \multicolumn{6}{|l|}{ Calcium levels (\%) } \\
\hline 2.85 & $70.46 \pm 1.10$ & $69.07 \pm 0.32$ & $107.78 \pm 0.46$ & $2.208 \pm 0.04$ & $1.935 \pm 0.05$ \\
\hline 3.65 & $71.93 \pm 0.94$ & $69.66 \pm 0.30$ & $106.51 \pm 0.57$ & $2.095 \pm 0.02$ & $1.780 \pm 0.02$ \\
\hline 4.45 & $74.59 \pm 0.63$ & $69.37 \pm 0.37$ & $106.51 \pm 0.49$ & $2.093 \pm 0.01$ & $1.776 \pm 0.03$ \\
\hline 5.25 & $70.38 \pm 0.80$ & $70.15 \pm 0.30$ & $107.10 \pm 0.29$ & $2.192 \pm 0.03$ & $1.886 \pm 0.03$ \\
\hline
\end{tabular}

\begin{tabular}{|c|c|c|c|c|c|}
\hline Vitamin D & * & * & NS & * & * \\
\hline Calcium levels & * & NS & NS & * & * \\
\hline Interaction & NS & NS & NS & NS & NS \\
\hline Regression & $\mathrm{Q}^{1}=4.12 \%$ & NS & NS & $Q^{2}=4.09 \%$ & $\mathrm{Q}^{3}=4.14 \%$ \\
\hline CV (\%) & 3.74 & 1.58 & 1.53 & 4.44 & 3.74 \\
\hline
\end{tabular}

a,b Means followed by different letters in the same column are different by the test of Tukey at $5 \%$ probability level. ${ }^{*}=$ Significant $(P<0.05)$. NS $=$ not significant.

$Q^{1}-\hat{Y}=36.06+18.241 x-22148 x^{2}\left(R^{2}=0.72\right) ; Q^{2}-\hat{Y}=3.464-0.677 x+0.0828 x^{2}\left(R^{2}=0.99\right) ; Q^{3}-\hat{Y}=3.5358-0.8574 x+0.1035 x^{2}\left(R^{2}=0.99\right)$.

produced heavier eggs $(\mathrm{p}<0.05)$ compared with those fed $1,25(\mathrm{OH})_{2} \mathrm{D}_{3}$, but not with those fed $\mathrm{D}_{3}(\mathrm{p}>0.05)$.

Eggshell percentage and thickness, and egg specific gravity linearly increased $(p<0.05)$ with increasing dietary calcium levels. Calcium plays an essential role in eggshell formation, and therefore, the increase in its dietary level contributed to better eggshell synthesis (Costa et al., 2008).
Albano Jr. et al. (2000) verified higher eggshell percentage and egg specific gravity as dietary calcium levels increased from 2 to $6 \%$. On the other hand, the tested vitamin D sources did not affect ( $p>0.05$ ) eggshell percentage and thickness or egg specific gravity.

Haugh units were not influenced $(p>0.05)$ by dietary calcium levels. However, the hens fed vitamin

Table 3 - Egg quality and bone strength of commercial layers in their second laying cycle fed diets with different vitamin D sources and calcium levels.

\begin{tabular}{|c|c|c|c|c|c|}
\hline Parameters & Eggshell \% & $\begin{array}{c}\text { Eggshell thickness } \\
(\mathrm{mm})\end{array}$ & $\begin{array}{c}\text { Egg specific gravity } \\
(\mathrm{g} / \mathrm{mL})\end{array}$ & Haugh units & $\begin{array}{c}\text { Bone strength } \\
\left(\mathrm{kgf} / \mathrm{cm}^{2}\right)\end{array}$ \\
\hline \multicolumn{6}{|l|}{ Vitamin D } \\
\hline Cholecalciferol & $8.16 \pm 0.07$ & $0.35 \pm 0.004$ & $1.075 \pm 0.0005$ & $97.64 \pm 0.22 a$ & $16.20 \pm 0.48$ \\
\hline 25-hydroxycholecalciferol & $8.08 \pm 0.07$ & $0.36 \pm 0.003$ & $1.075 \pm 0.0005$ & $97.27 \pm 0.16 a b$ & $15.53 \pm 0.41$ \\
\hline 1,25-dihydroxycholecalciferol & $8.16 \pm 0.09$ & $0.35 \pm 0.004$ & $1.076 \pm 0.0006$ & $96.96 \pm 0.20 b$ & $15.65 \pm 0.41$ \\
\hline \multicolumn{6}{|l|}{ Calcium levels (\%) } \\
\hline 2.85 & $7.81 \pm 0.07$ & $0.34 \pm 0.003$ & $1.073 \pm 0.001$ & $97.63 \pm 0.22$ & $14.96 \pm 0.41$ \\
\hline 3.65 & $8.08 \pm 0.05$ & $0.35 \pm 0.003$ & $1.075 \pm 0.004$ & $97.43 \pm 0.22$ & $15.55 \pm 0.29$ \\
\hline 4.45 & $8.36 \pm 0.05$ & $0.36 \pm 0.002$ & $1.077 \pm 0.003$ & $97.20 \pm 0.25$ & $15.75 \pm 0.57$ \\
\hline 5.25 & $8.28 \pm 0.06$ & $0.37 \pm 0.004$ & $1.078 \pm 0.005$ & $96.86 \pm 0.22$ & $16.91 \pm 0.47$ \\
\hline
\end{tabular}

$\begin{array}{lccccc}\text { Vitamin D } & \text { NS } & \text { NS } & \text { NS } & * & \text { NS } \\ \text { Calcium levels } & * & * & * & \text { NS } & \text { NS } \\ \text { Interaction } & \text { NS } & \text { NS } & L^{3} & \text { NS } & L^{4} \\ \text { Regression } & L^{1} & L^{2} & 0.12 & 0.76 & 3.74 \\ \text { CV }(\%) & 2.64 & 3.16 & \text {. }\end{array}$

a,b Means followed by different letters in the same column are different by the test of Tukey at $5 \%$ probability level.

${ }^{*}=$ Significant $(p<0.05)$. NS = not significant. $L^{1}-\hat{Y}=7.2769+0.2113 x\left(R^{2}=0.79\right) ; L^{2}-\hat{Y}=0.3044+0.0125 x\left(R^{2}=1\right) ; L^{3}-\hat{Y}=1.0671+0.0021 \times\left(R^{2}=0.97\right) ; L^{4}-\hat{Y}=12.73+0.7563 x$ $\left(R^{2}=0.91\right)$. 
$D_{3}$ presented better $\mathrm{HU}$ results $(\mathrm{p}<0.05)$ compared with those fed $1,25(\mathrm{OH})_{2} \mathrm{D}_{3}$, but similar $\mathrm{HU}$ as those fed $25(\mathrm{OH}) \mathrm{D}_{3}$. The results obtained with $1,25(\mathrm{OH})_{2} \mathrm{D}_{3}$ may be attributed to the shorter half-life of this metabolite (4-6 hours), compared with $25(\mathrm{OH}) \mathrm{D}_{3}$ (2-3 weeks) (Castro, 2011), and therefore its utilization may have been impaired due to the lack of body reserves.

Bone strength linearly increased $(p<0.05)$ with calcium levels. When calcium blood levels are high, the $C$ cells of the ultimobranchial glands are stimulated to secrete calcitonin, reducing bone resorption and consequently, increasing bone strength (Whitehead, 2004; Nunes et al., 2006).

Bone strength was not affected ( $p>0.05)$ by the tested vitamin $\mathrm{D}$ sources, despite the absorption rate of $25(\mathrm{OH}) \mathrm{D}_{3}$ is higher than that of vitamin $\mathrm{D}_{3}$ (Applegate \& Angel, 2005) and $1,25(\mathrm{OH})_{2} \mathrm{D}_{3}$ increased calcium absorption by the intestine (Grüdtner et al., 1997). This result may be attributed to the fact that the activity of cholecalciferol, $25(\mathrm{OH}) \mathrm{D}_{3}$, and $1,25(\mathrm{OH})_{2} \mathrm{D}_{3}$ depend on the biological response of birds (Aburto et al., 1998). Sahin et al. (2009) obtained better bone mineralization in laying quails when $25(\mathrm{OH}) \mathrm{D}_{3}$ was added to the diet.

Vitamin D sources did not influence ( $p>0.05)$ blood calcium levels $(\mathrm{mg} / \mathrm{dL}$ ) in none of the blood collections performed at different times after lay, as shown in Table 4.

Layers maintain balanced calcium and phosphorus blood levels for eggshell formation (Junqueira et al., 2002), independently of vitamin D source. Considering the measurement of vitamin $D$ sources, the level of the metabolite $25(\mathrm{OH}) \mathrm{D}_{3}$ provides the best indication of vitamin D blood levels (Barral et al., 2007), as the $1,25(\mathrm{OH})_{2} \mathrm{D}_{3}$ level reflects calcium homeostasis.

The different metabolite types did not influence the concentration of $1,25(\mathrm{OH})_{2} \mathrm{D}_{3}$, which induces the release of the $\mathrm{Ca}^{2+}$ ion for calcium deposition in the eggshell, thereby affecting eggshell quality (Bar et al.,
1999). This effect on calcium deposition characteristics was observed in the present study, as shown by the lack of effect of the tested vitamin $D$ metabolites on the eggshell quality of layers in their second laying cycle.

\section{CONCLUSIONS}

Considering the egg production and feed conversion ratio $(\mathrm{kg} / \mathrm{kg}$ and $\mathrm{kg} / \mathrm{dz}$ ) results obtained in the present study, 4.09 and $4.14 \%$ dietary calcium levels are recommended for layers in their second laying cycle, respectively. Cholecalciferol and 25-hydroxycholecalciferol improved production performance and egg quality. Bone strength and serum calcium levels were not influenced by the tested vitamin D metabolites. Bone strength increased with increasing dietary calcium levels.

\section{REFERENCES}

Aburto A, Edwards Junior HM, Britton WM. The Influence of vitamin A on the utilization and amelioration of toxicity of cholecalciferol, 25 hydroxycholecalciferol, and 1.25-dihydroxycholecalciferol in young broiler chickens. Poultry Science 1998;77(4):585-593.

Albano Jr M, Albuquerque R, Lima CG, Ghion E, Lima FR, Morais CSD. Desempenho e qualidade dos ovos de diferentes linhagens de poedeiras comerciais pós-muda forçada recebendo rações com níveis variáveis de cálcio. Brazilian Journal Veterinary Research Animal Science 2000;37(4)

Applegate TJ, Angel R. Los metabolitos de la vitamina D son prometedores para uso en dietas avícolas. In: Vademécum Avícola. Santiago: Centrovet; 2005.

Araújo JA, Silva JHV, Costa FGP, Souza JMB, Givisiez PEN, Sakomura NK Effect of the levels of calcium and particle size of limestone on laying hens. Revista Brasileira de Zootecnia 2011;40(5)

Bar A, Vax E, Striem S. Relationships among age, eggshell thickness and vitamin D metabolism and its expression in the laying hens. Comparative Biochemistry and Physiology 1999;123:147-154

Barral D, Barros AC, Araújo RPC. Vitamina D: Uma abordagem molecular. Pesquisa Brasileira Odontopediatria Clínica e Integrada 2007:7(3):309315.

Table 4 - Blood calcium levels (mg/dL) of layers fed different vitamin D sources as evaluated at different times after lay.

\begin{tabular}{|c|c|c|c|c|c|}
\hline \multirow[b]{2}{*}{ Hours after lay } & \multicolumn{3}{|c|}{ Calcium (mg/dL) } & \multirow[t]{2}{*}{$\mathrm{P}$} & \multirow[t]{2}{*}{$\mathrm{CV}(\%)$} \\
\hline & Cholecalciferol & 25-hydroxycholecalciferol & 1,25-dihydroxycholecalciferol & & \\
\hline 1 & $12.32 \pm 0.97$ & $13.48 \pm 0.74$ & $13.44 \pm 1.11$ & NS & 8.88 \\
\hline 6 & $14.20 \pm 0.23$ & $14.60 \pm 0.23$ & $14.41 \pm 0.26$ & NS & 6.64 \\
\hline 12 & $19.68 \pm 0.22$ & $20.08 \pm 0.28$ & $19.58 \pm 0.22$ & NS & 4.84 \\
\hline 18 & $25.33 \pm 0.66$ & $25.52 \pm 1.39$ & $25.51 \pm 0.72$ & NS & 15.14 \\
\hline 24 & $13.89 \pm 0.43$ & $13.35 \pm 0.42$ & $14.16 \pm 0.34$ & NS & 11.52 \\
\hline Mean & $17.09 \pm 0.60$ & $17.40 \pm 0.63$ & $17.42 \pm 0.59$ & NS & 21.06 \\
\hline
\end{tabular}

${ }^{*}$ Test of Tukey $(p>0.05)$. NS = not significant. 


\section{Effect of Different Vitamin D Sources and Calcium Levels in the Diet of Layers in the Second Laying Cycle}

Nunes RV, Pozza PC, Scherer C, Campestrini E, Rocha LD, Nunes CGV, Costa FGP. Efeito dos teores de cálcio para poedeiras semipesadas durante a fase de pré-postura e no início da postura. Revista Brasileira de Zootecnia 2006;35(5)

Pedrosa MAC, Castro ML. Papel da vitamina D na função neuro-muscular. Arquivo Brasileiro de Endocrinologia e Metabologia 2005;49,(4).

Pelícia K, Garcia EA, Faitarone ABG, Silva AP, Berto DA, Molino AB, Vercese F. Calcium and available phosphorus levels for laying hens in second production cycle. Brazilian Journal of Poultry Science 2009;11(1):3949.

Rodrigues EA, Junqueira OM, Valério M, Andreotti MO, Cancherini LC, Faria DE, Filardi RS. Níveis de cálcio em rações de poedeiras comerciais no segundo ciclo de postura. Acta Scientiarum 2005;27(1):49-54.

Rostagno HS, Albino LFT, Donzele JL, Gomes PC, Ferreira AS, Lopes DC, Oliveira RFM. Tabelas brasileiras para aves e suínos: composição de alimentos e exigências nutricionais. $3^{a}$ ed. Viçosa: Universidade Federal de Viçosa; 2011

Sahin, N.; Balci, T.A.; Kucuk, O.; Smith, M.O.; Sahin, K. Effects of 25-hydroxycholecalciferol and soy isoflavones supplementation of bone mineralization of quail. British Poultry Science, n. 6, v. 50, , p. 709-715, 2009

Salvador D, Faria DE, Mazalli MR, Ito DT, Faria Filho DE, Araújo L.F. Vitaminas D e C para poedeiras na fase inicial de produção de ovos. Revista Brasileira de Zootecnia 2009;38(5).

Universidade Federal De Viçosa. SAEG - Sistema de análises estatísticas e genéticas. Versão 5.0. Viçosa, MG; 2005

Whitehead CC. Overview of bone biology in the egg-layin hen. Poultry Science, Champaign 2004;83(1):193-199. 